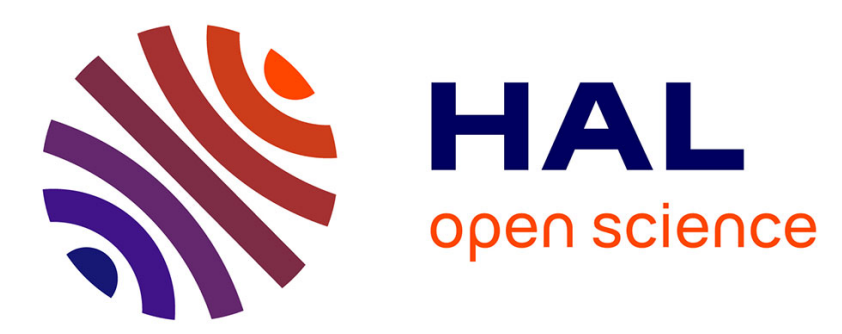

\title{
Laser induced fluorescence determination of electric fields in R.F. discharges
}

\author{
J. Booth, M. Fadlallah, J. Derouard, N. Sadeghi
}

\section{To cite this version:}

J. Booth, M. Fadlallah, J. Derouard, N. Sadeghi. Laser induced fluorescence determination of electric fields in R.F. discharges. Journal de Physique IV Proceedings, 1994, 04 (C4), pp.C4-777-C4-777. 10.1051/jp4:19944217 . jpa-00252684

\section{HAL Id: jpa-00252684 https://hal.science/jpa-00252684}

Submitted on 1 Jan 1994

HAL is a multi-disciplinary open access archive for the deposit and dissemination of scientific research documents, whether they are published or not. The documents may come from teaching and research institutions in France or abroad, or from public or private research centers.
L'archive ouverte pluridisciplinaire HAL, est destinée au dépôt et à la diffusion de documents scientifiques de niveau recherche, publiés ou non, émanant des établissements d'enseignement et de recherche français ou étrangers, des laboratoires publics ou privés. 


\title{
Laser induced fluorescence determination of electric fields in R.F. discharges
}

\author{
J.P. BOOTH, M. FADLALLAH, J. DEROUARD and N. SADEGHI
}

Lab. de Spectrométrie Physique, Univ. Grenoble I, BP. 87, 38402 Saint Martin d'Hères, France

\begin{abstract}
A knowledge of the temporal and spatial variations of the electric field in radiofrequency gas discharges is essential for rigourous testing of the numerous selfconsistent models that have been recently proposed for the charged particle behaviour. We have develloped a new method for the non-perturbative in-situ determination of electric fields, based on laser induced fluorescence of Rydberg state $\mathrm{H}$ atoms present in $\mathrm{H}_{2}$-containing discharges. The atoms are excited to the $n=2$ state by two photons at $243 n m$, then further excited to $n=6$ by one photon at $410 \mathrm{~nm}$, with detection of the $\mathrm{H} \alpha$ emission, produced by radiative and collisional cascading. A system comprising two dye lasers pumped in parallel by a single $\mathrm{XeCl}$ excimer laser is used to accomplish this. Analysis of the Stark splitting of the $n=6$ state, observed from the structure of the 2-6 excitation profile, allows the electric field to be determined. Results are presented for $30 \mathrm{kHz}$, 1Torr $\mathrm{H}_{2}$ discharges, with temporal (30ns) and spatial $(0.5 \mathrm{~mm})$ resolution and detection of fields as low as $20 \mathrm{~V} / \mathrm{cm}$. As well as the previously observed temporal asymmetry of the cathode sheath 1 , we have measured fields of up to $70 \mathrm{~V} / \mathrm{cm}$ close to the electrode in the anodic half-cycle.
\end{abstract}

1J.P.Booth, J.Derouard, M.Fadlallah, and N.Sadeghi, J.Appl.Phys. 74, 862, (1993) 